\title{
Natural and human-induced variability in the composition of fish assemblages in the Northwestern Cuban shelf
}

\author{
Gaspar González-Sansón ${ }^{1 *}$, Consuelo Aguilar ${ }^{1}$, Ivet Hernández ${ }^{1}$, Yureidy Cabrera ${ }^{1}$, Noelis \\ Suarez-Montes ${ }^{2}$, Fernando Bretos ${ }^{3} \&$ David Guggenheim ${ }^{3}$ \\ 1. Centro de Investigaciones Marinas de la Universidad de la Habana, Calle 16 No. 114, Miramar, Ciudad de La Habana, \\ Cuba; gaspargonzalez2001@yahoo.es; cab@cim.uh.cu; ivet@cim.uh.cu; ycabrera@cim.uh.cu \\ 2. Establecimiento Pesquero de Los Arroyos, Los Arroyos, Pinar del Rio, Cuba; arroyos@telemar.cu \\ 3. Harte Research Institute for Gulf of Mexico Studies, Texas A\&M University-Corpus Christi, 6300 Ocean, Unit 5869, \\ Corpus Christi, Texas 78412, México; nandobretos@yahoo.com; dguggenh@yahoo.com \\ * Corresponding author.
}

Received 03-II-2008. Corrected 03-XII-2008. Accepted 03-I-2009.

\begin{abstract}
The main goal of the study was to obtain field data to build a baseline of fish assemblage composition that can be used comparatively for future analyses of the impact of human actions in the region. A basic network of 68 sampling stations was defined for the entire region $\left(4050 \mathrm{~km}^{2}\right)$. Fish assemblage species and size composition was estimated using visual census methods at three different spatial scales: a) entire region, b) inside the main reef area and c) along a human impact coastal gradient. Multivariate numerical analyses revealed habitat type as the main factor inducing spatial variability of fish community composition, while the level of human impact appears to play the main role in fish assemblage composition changes along the coast. A trend of decreasing fish size toward the east supports the theory of more severe human impact due to overfishing and higher urban pollution in that direction. This is the first detailed study along the northwest coast of Cuba that focuses on fish community structure and the natural and human-induced variations at different spatial scales for the entire NW shelf. This research also provides input for a more comprehensive understanding of coastal marine fish communities' status in the Gulf of Mexico basin. Rev. Biol. Trop. 57 (3): 721-740. Epub 2009 September 30.
\end{abstract}

Key words: fish assemblages, Caribbean, Gulf of Mexico, human impact, spatial scale.

The coastal waters of Cuba are unique in the marine ecological context of the Gulf of Mexico (González-Sansón and Aguilar 2004). The northwestern region of Cuba marks the southeastern limit of the Gulf of Mexico. The Cuban archipelago, nevertheless, is typically Caribbean based on the nature of its predominant marine ecosystems with the northwest region no exception. In addition, a high level of connectivity due to surface current patterns exists between the NW region of Cuba and other coastal areas of the Gulf basin, mainly Florida (Paris et al. 2005).

Overfishing is the most important human impact in the region. Target species are mediumand large-bodied fishes mainly of the families
Lutjanidae (snappers), Serranidae (groupers), Carangidae (jacks), and Sphyraenidae (barracudas). This selective overfishing alters species composition (Aguilar et al. 2004) and increases the dominance of smaller species (Baisre 2000), similar to changes seen on Jamaican coral reefs (Hughes 1994) and on coral reefs of the IndoPacific Region (Harmelin-Vivien 1992). The resulting fish assemblages have a high level of diversity and are dominated by smaller-bodied species of the families Pomacentridae (damselfishes), Labridae (wrasses), Scaridae (parrotfishes) and Acanthuridae (surgeonfishes).

Another important anthropogenic impact is land-based pollution in several specific localities. The best-known case is that of the bay 
of Havana, home to the most important port of the country (UNEP 2004). The impact of contaminated bay waters on the coastal zone has been documented in several studies on the marine fauna (Herrera and Alcolado 1983, Herrera 1984, Herrera and Martinez-Estalella 1987, Guardia y González-Sansón, 2000 a, b), including fishes (Aguilar et al. 2004, 2007, 2008). The effect of the Almendares River on the marine fauna of the associated coastal zone has been documented in a series of recent studies (Guardia et al. 2001, Aguilar and GonzálezSansón 2002, González-Sansón and Aguilar 2002, Aguilar et al. 2008). Other rivers of the region present some degree of contamination, but published data examining the amount and type of polluting agents does not yet exist. Recently the government of the Republic of Cuba announced plans to negotiate contracts with foreign companies for the exploration of gas and petroleum in deep waters of the exclusive economic zone of Cuba in the Gulf of Mexico. The effective prognosis and mitigation of potential accidents support the need for base line databases.

Fish assemblages are good indicators of human impacts (Adams 2002). The ecological response to these impacts is most evident at the community level. It is difficult to accurately determine cause-effect relationships at this level (Munkittrik et al. 2000). To identify changes due to human impacts reliable baseline data is required not only of the average composition of fish assemblages but also of their current levels of variation at different spatial scales.

Habitat type has been found to be one of the most important factors determining spatial variation in the structure of coastal fish assemblages (Gladfelter and Gladfelter 1978, Luckhurst and Luckhurst 1978, Bell and Galzin 1984, Roberts and Ormond 1987, Aburto-Oropeza and Balart 2001, Claro et al. 2001, Letourneur et al. 2003, Gratwicke and Speight 2005, Gratwicke et al. 2006). NúñezLara et al. (2005) found that geomorphologic and anthropogenic factors indeed influenced reef fish community composition. Feary et al. (2008) presented evidence suggesting that habitat health may play an important role in structuring coral-associated fish assemblages. Hydrological variables (salinity, temperature, dissolved oxygen, etc.) can play a role in fish assemblage structure in costal waters (Fock et al. 2002, Barletta et al. 2005, Costa de Azevedo et al. 2006). When analyzing factors shaping fish assemblages in coastal waters it is very important to determine if a gradient in water characteristics is present.

This is the first detailed study along the NW coast of Cuba that focuses on fish community structure and its natural and humaninduced variations at different spatial scales for the entire NW Cuban shelf. The main goal of the study was to obtain baseline field data of fish assemblage composition that can be used as a reference for future analyses of the impact of human actions in the region (e.g. oil spills, change in fishing intensity, other pollution events, tourism development). This research also provides input for a more comprehensive understanding of fish community status in the Gulf of Mexico basin.

\section{MATERIALS AND METHODS}

Study area: The study was conducted along the northwestern region of the Cuban shelf. Predominant shallow-water habitats in this region are fringing coral reefs and sea grass beds. The estimated total surface area of this shelf region is $4050 \mathrm{~km}^{2}$. The mean depth is 4-5 m, although in some places of the Gulf of Guanahacabibes the depth can reach $18 \mathrm{~m}$.

The region can be divided in two main subregions (Fig. 1). The western subregion (Fig. 1A) extends from San Antonio Cape (21 ${ }^{\circ} 52^{\prime}$ $\left.\mathrm{N}, 84^{\circ} 58^{\prime} \mathrm{W}\right)$ to Gobernadora point $\left(22^{\circ} 59^{\prime} \mathrm{N}\right.$, $\left.83^{\circ} 13^{\prime} \mathrm{W}\right)$. It is wide, extending $50 \mathrm{~km}$ from the coast line to the shelf edge in the Gulf of Guanahacabibes. Well developed mangrove forests are present along the shore and in the outlying keys. The eastern subregion (Fig. 1B) extends from Gobernadora point to Havana bay $\left(23^{\circ} 09^{\prime} \mathrm{N}, 82^{\circ} 21^{\prime} \mathrm{W}\right)$. It consists of a very narrow shelf, only a kilometer wide. The shoreline 

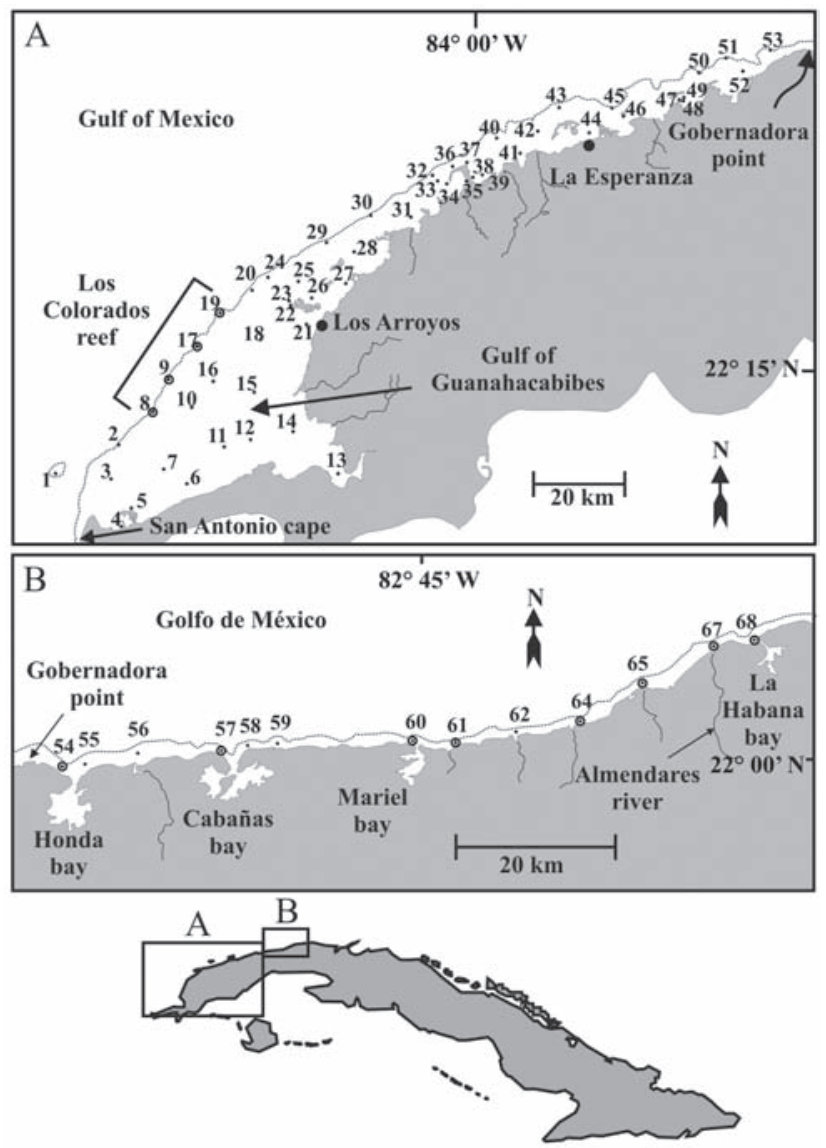

Fig. 1. Western (A) and eastern (B) subregions of the NW region of the Cuban shelf. The network of fixed sampling stations is shown. Stations with a circle are those included in the study of the human impact gradient along the coast.

is mostly rocky with scarce mangrove growth, which is mainly found in estuarine areas at the river mouths. A basic network of 68 fixed sampling stations was defined (Fig. 1). Coordinates of sampling stations are available on request. Spatial variability of fish assemblages' composition was investigated at three main spatial dimensions, as is described below.

Sampling designs: At the entire region level (a scale of hundreds to thousands of square kilometers), we investigated spatial variation in fish assemblages and concordance with differences in major habitat types (i.e. sea grass beds, coral reefs). To achieve this goal, the majority of stations were sampled in
January and June 2004. As the ichthyofauna of Havana Bay (stations 67 and 68) has been investigated at a finer scale for several years, it is the only zone not included in this study. Results from these studies are published elsewhere (Aguilar et al. 2004).

Inside the most heterogeneous habitat, namely the coral reefs (a scale of one to tens of square kilometers), two dimensions were of interest: i) changes along the shelf edge, related to distance from land and human access, ii) differences among the main reef habitat types (i.e. Acropora crests, terrace, spur and grooves zones). For this purpose, a subset of four stations $(8,9,17$ and 19) was sampled in March 2006. These stations are positioned at the core 
of the bank-barrier reef of "Los Colorados", which is the most important reef system of the region. At each station three habitat types were sampled, namely Acropora crest, terrace and spur and grooves.

We also sampled fish assemblages along a gradient of human impact (Table 1, Fig. 1) from heavily populated and polluted areas (Havana bay) to cleaner areas (Honda bay) to non polluted areas in the west (Colorados Reef). This represents a longitudinal scale of hundreds of kilometers. A subset of twelve stations $(8,9$, $17,19,54,57,60,61,64,65,67$ and 68) was sampled in March and April 2006. A single but representative habitat type, which is present in all sampling stations, was selected for sampling (terrace at 12-15 $\mathrm{m}$ depth).

Abiotic variables and bottom types: During the sampling period of 2004, a vertical profile for selected variables was measured at each station using a Hydrolab 4 probe. Variables included were water temperature $\left({ }^{\circ} \mathrm{C}\right)$, salinity (practical salinity scale), depth (meters), oxygen concentration (mg/l) and oxygen saturation (\%). Transparency of the water was measured using a conventional Secchi disk of $30 \mathrm{~cm}$ in diameter. At each station a survey

TABLE 1

Main characteristics and assumed human impact level in the stations selected for the study along the shelf edge (terrace) of the $\mathrm{NW}$ region

\begin{tabular}{|c|c|c|c|}
\hline $\begin{array}{l}\text { Station } \\
\text { number }\end{array}$ & Geographical place & $\begin{array}{l}\text { Characteristics of human impact } \\
\text { (Overfishing is present in all stations) }\end{array}$ & $\begin{array}{l}\text { Coastal } \\
\text { pollution } \\
\text { and/or } \\
\text { degradation }\end{array}$ \\
\hline 8 & $\begin{array}{l}\text { Los Colorados } \\
\text { reef }\end{array}$ & No pollution sources. Farthest from any populated area. & Very low \\
\hline 9 & $\begin{array}{l}\text { Los Colorados } \\
\text { reef }\end{array}$ & No pollution sources. Far from any populated area. & Very low \\
\hline 17 & $\begin{array}{l}\text { Los Colorados } \\
\text { reef }\end{array}$ & No pollution sources. Far from any populated area. & Very low \\
\hline 19 & $\begin{array}{l}\text { Los Colorados } \\
\text { reef }\end{array}$ & $\begin{array}{l}\text { No pollution sources. Relatively near to a small fishermen } \\
\text { village. }\end{array}$ & Very low \\
\hline 54 & Entrance of Honda bay & $\begin{array}{l}\text { Small town near the bay. A port with very low activity. } \\
\text { Some organic and oil pollution. }\end{array}$ & Low \\
\hline 57 & Entrance of Cabañas bay & $\begin{array}{l}\text { Small town near the bay. A port with low activity. Some } \\
\text { organic and oil pollution. }\end{array}$ & Low \\
\hline 60 & Entance of Mariel bay & $\begin{array}{l}\text { Small city near the bay. The bay is a port with much less } \\
\text { activity than Havana's and is polluted with untreated } \\
\text { sewage and petroleum. There is a big cement factory. }\end{array}$ & Medium \\
\hline 61 & Mouth of Mosquito river & $\begin{array}{l}\text { Far from highly populated areas. Organic pollution and } \\
\text { some nutrient impact from agriculture }\end{array}$ & Medium \\
\hline 64 & Baracoa beach & $\begin{array}{l}\text { Far from highly populated areas. A small village. Organic } \\
\text { pollution coming mainly from nearby rivers. }\end{array}$ & Medium \\
\hline 65 & $\begin{array}{l}\text { Mouth of Jaimanitas } \\
\text { river }\end{array}$ & $\begin{array}{l}\text { River flows a less populated neighborhood of Havana city. } \\
\text { Polluted with untreated sewage. }\end{array}$ & Medium \\
\hline 67 & $\begin{array}{l}\text { Mouth of Almendares } \\
\text { river }\end{array}$ & $\begin{array}{l}\text { River flows across a heavy populated area of Havana City. } \\
\text { Very polluted with untreated sewage \& heavy metals. }\end{array}$ & High \\
\hline 68 & Entance of Havana bay & $\begin{array}{l}\text { Population of Havana City: } 2.5 \text { million } \\
\text { The bay is the most important Cuban port and is very } \\
\text { polluted with untreated sewage, petroleum \& heavy metals. }\end{array}$ & Very high \\
\hline
\end{tabular}


using SCUBA and underwater video was carried out to determine the main characteristics of the substrate and bottom communities including both plants and animals. An exhaustive analysis of this data will be explored in a future paper, while here only main types of substrate identified during the survey will be included to support fish assemblage analyses.

Fish census methods: For the semi-quantitative, large scale study in the entire region a rover-diver method was used (Baron et al. 2004). At each sampling station two divers covered as much area as possible during 20 minutes. During these dives every species of fish and its' relative abundance was recorded. At the end of the dive both observers shared their observations, made a careful review of the video-taped material and for each species agreed on a ranking according to its abundance and dominance at the dive site. The rank scale was: 1: for present, when less than ten individuals were seen during the dive; 2: for abundant, when more than ten individuals were seen, but the species was not dominant; 3: for dominant, when the species was abundant and clearly dominated the assemblage composition at the site.

For the quantitative study conducted at Colorados Reef and along the shelf edge at the terrace, the stationary visual census technique of Bohnsack and Bannerot (1986) was used with some minor modifications. The radius of the observing cylinder was five meters and fish were allocated to length classes instead of attempting to determine the length of each fish in centimeters. At each sampling station two or three observers made 15 censuses or more simultaneously and the data were pooled after each dive to estimate fish abundance and length composition at each station. Data are given as the number of individuals per census. The minimum of 15 censuses was determined based on results obtained in previous research conducted in similar areas of the Northwestern region (Aguilar et al. 1997, Aguilar et al. 2004).

Fisheries statistics: An analysis of commercial catch composition was made to complement visual census techniques. Fisheries operate in mixed spatial scales and are very biased as sampling methods but they can provide useful additional information. Main sources of catch statistics were a printed statistical report by the Cuban Central Board of Planning (JUCEPLAN) from 1959 to 1973 and recent information provided by the Center of Fisheries Research of the Cuban Ministry of Fisheries from 2000 to 2003 (S. Valle, pers. com.). In both cases data refer to the two main fishery ports in the NW region, namely Los Arroyos $\left(22^{\circ} 20^{\prime} \mathrm{N}, 84^{\circ} 22^{\prime} \mathrm{W}\right)$ and La Esperanza (22 ${ }^{\circ} 46^{\prime}$ $\mathrm{N}, 83^{\circ} 44^{\prime} \mathrm{W}$ ). Only shelf dwelling finfishes were included in the analysis. This excludes data from a small tuna fishery, which develop in oceanic waters near the shelf edge.

Numerical analyses: A species accumulation curve was prepared to check if the number of stations sampled was enough to give a reliable estimate of the species number at the entire region scale. This kind of curve records the total number of species, as additional sample units (in our case sampling stations) are added to the pool of all previously observed samples (Gotelli and Colwell 2001). Before the pooling process, stations were ordered randomly.

For quantitative data obtained by stationary visual census we tested the null hypothesis of zero differences in mean numbers among the stations sampled. Data on fish number obtained by visual censuses at the scales of one to tens of kilometers (coral reef) and hundreds of kilometers (gradient of human impact) were compared using standard fixed-effects ANOVAs. Data were explored for assumptions (normality and variance homogeneity) and transformed when necessary. A bifactorial ANOVA was made on fourth-root transformed data to search for significant differences in the mean total abundance among habitat types and stations. In the event ANOVAs yielded significant differences between stations included in the analyses, the Student-Newman-Keuls (SNK) post-hoc multiple comparisons test for means was applied. The variability measurement accompanying mean values is always the standard error of the mean. 
For all data taken at all spatial scales, we explored the homogeneity of species composition of fish assemblages using multidimensional analyses. Agglomerative cluster analyses were performed using dissimilarity measures $1-r_{s}$, $\left(r_{s}=\right.$ Spearman's rank correlation coefficient) for semi-quantitative data (entire region study) and the Bray-Curtis distance on log transformed abundance data for quantitative data (those gathered by stationary visual census). In all cases, the UPGMA clustering algorithm was used. Non parametric multidimensional scaling (MDS) was employed for ordination of sampling sites based in same distance matrices as cluster analyses. Clarke and Warwick (2001) have explicitly considered the combination of clustering and ordination analysis as a very effective way of checking the adequacy and mutual consistency of both methods. Therefore, both techniques were applied to data and their results used reciprocally to interpret the primary data matrix structure. Original data matrix was reduced using two criteria to remove very rare species, or stations which showed a scarcity of fish. First, all species appearing in less than $20 \%$ of the stations were eliminated. Secondly, all stations where the sum of ranks was less than five were deleted. The SIMPER routine was used to find main discriminating species in groups of samples obtained with quantitative data. All analyses were made using PRIMER ${ }^{\circledR} 5$ and STATISTICA ${ }^{\circledR} 6.0$ software.

\section{RESULTS}

Abiotic factors: Seawater over the shelf was very well mixed and stratification was present only in a few stations and was very weak. For that reason, we pooled all data from all depths to obtain representative values for the region. The variable that showed most variation between sampling seasons and among sampling stations was water temperature. However, a difference of only $5.6{ }^{\circ} \mathrm{C}$ was found between the mean values for winter (January) and summer (June). The horizontal variation was smaller and the difference between the lowest and the highest values was $4.3^{\circ}$ and $3.4^{\circ} \mathrm{C}$ in winter and summer respectively. Seasonal, vertical and horizontal variation in other variables was negligible (Table 2).

Main bottom habitats in the western portion of the NW region were sea grass beds ( $51 \%$ of the stations), which are present at more

TABLE 2

Mean values of water abiotic variables in the NW Region of the Cuban shelf

$\begin{array}{cccccc}\text { Variable } & \text { Zone } & \text { Month } & \text { Mean } & \text { Min } & \text { Max } \\ \text { Temperature } & \text { W } & \text { Jan } & 23.1 & 21.3 & 25.6 \\ { }^{\circ} \mathrm{C} & \text { W } & \text { Jun } & 28.7 & 27.2 & 30.6 \\ & \text { E } & \text { Jun } & 27.2 & 26.8 & 28.7 \\ \text { Salinity } & \text { W } & \text { Jan } & 37.1 & 35.4 & 37.8 \\ \text { PSS } & \text { W } & \text { Jun } & 36.7 & 36.4 & 37.1 \\ & \text { E } & \text { Jun } & 36.6 & 35.5 & 36.7 \\ \text { Oxygen } & \text { W } & \text { Jan } & 6.8 & 5.0 & 8.3 \\ \text { mg/l } & \text { W } & \text { Jun } & 6.2 & 4.9 & 7.4 \\ \text { Saturation } & \text { E } & \text { Jun } & 6.5 & 5.8 & 8.4 \\ \text { O } 2 \text { (\%) } & \text { W } & \text { Jan } & 99.6 & 74.8 & 122.4 \\ & \text { W } & \text { Jun } & 99.9 & 79.8 & 118.9 \\ \text { pH } & \text { E } & \text { Jun } & 102.2 & 92.9 & 126.7 \\ & \text { W } & \text { Jan } & 8.26 & 7.84 & 8.38\end{array}$

$\mathrm{W}=$ western portion; $\mathrm{E}=$ eastern portion; Jan = January 2004; Jun = June 2004. 


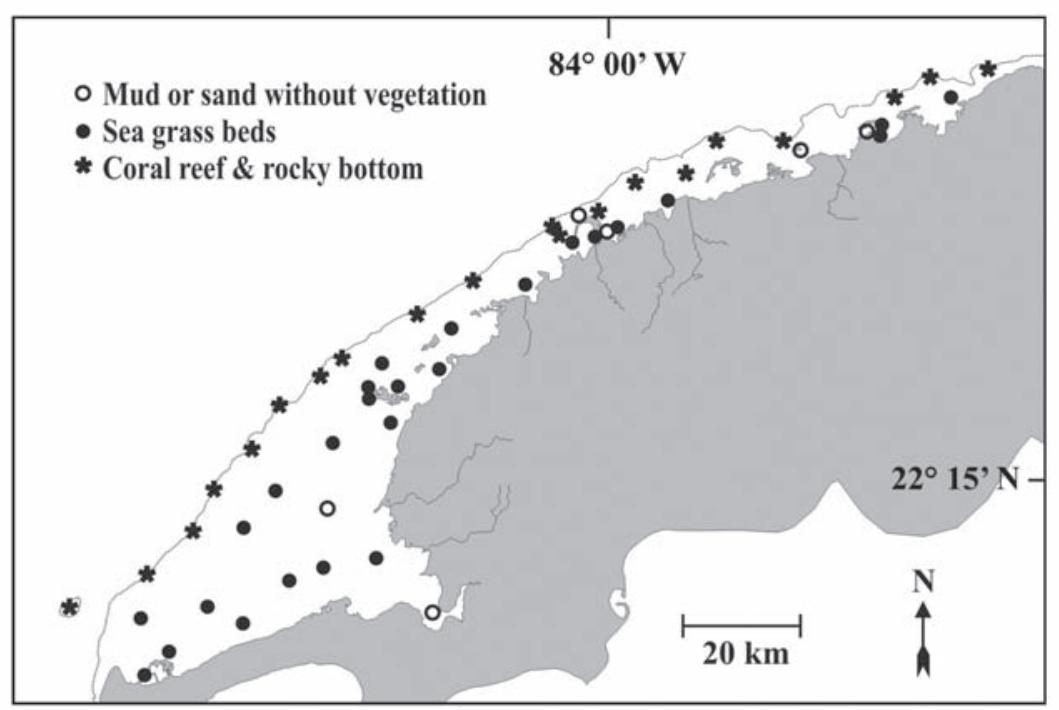

Fig. 2. Main substrate types found in the western subregion of the Cuban NW region. Symbols are located at fish sampling stations.

nearshore sites and coral reefs (38\% of the stations), which dominate the shelf edge as fringe and bank-barrier reefs (Fig. 2). In the eastern portion of the shelf the dominant bottom type was rocky with moderately developed reef formations (mostly in the terrace) and small patches of sand.

Fish assemblages. Whole region: A total of 143 species of teleost fish were identified during the surveys of the 68 sampling stations. In five stations no fish were seen. The plot of cumulative number of species over cumulative number of stations (randomly ordered) yielded a clearly asymptotic curve (Fig. 3). This indicates that sampling effort was enough to have a good estimate of the non-criptic fish species richness in this region. After the sum of their ranks for the entire set of samples and the number of stations where they were seen was established, we identified the most common species for the whole region as: Bluehead (Thalassoma bifasciatum Bloch), Princess/Striped parrotfish complex (Scarus taeniopterus Desmarest $+S$. iseri (Bloch)), Bicolor damselfish (Stegastes partitus (Poey)),
White grunt (Haemulon plumieri (Lacepède)), Blue chromis (Chromis cyanea (Poey)), Ocean surgeonfish (Acanthurus bahianus Castelnau) and French grunt (Haemulon flavolineatum (Desmarest)).

For multivariate analyses, the original matrix of 143 species and 63 stations was reduced to a new matrix with 52 species and 50 stations. The classification yielded two main groups of stations corresponding to inner stations (Group A), on seagrass beds and outer

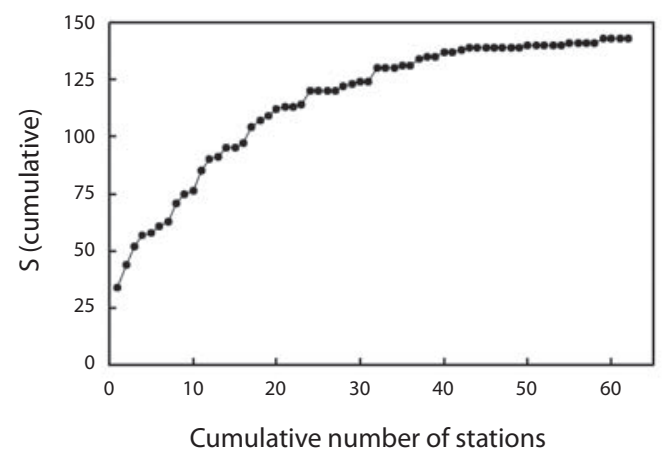

Fig. 3. Cumulative number of species (S) for the whole Cuban NW region. 
stations (Group B), on reefs or hard bottoms respectively (Fig. 4). The MDS ordination of the samples showed a stress value of 0.22 for two dimensions, which can not be considered acceptable. For that reason we made a second ordination using three dimensions, which yielded a stress value of 0.15 (Fig. 4). The joint analysis of both representations confirms their reliability for illustrating the main structure of the primary data matrix.

Four subgroups are weakly suggested in group B stations by classification/ordination results (Fig. 4). In the first subgroup of stations (B1) dominant species were Bluehead, Princess/Striped parrotfish, Redband parrotfish (Sparisoma aurofrenatum (Valenciennes)) and Blue Tang (Acanthurus coeruleus Schneider). The four stations included are very distant from each other and share the characteristic of being far from the shelf edge. In subgroup B2, fish assemblage was clearly dominated by Bluehead and Bicolor damselfish with Princess/Striped parrotfish and Redband parrotfish also common. Most of the stations are included in this subgroup. These stations are positioned near the shelf edge (considerable oceanic influence) in the western portion of the NW region or are stations located in the eastern portion, where the shelf is so narrow that ocean influence is greater. Most common species in subgroup B3 were planktivore reef fish including Blue chromis, Creole wrasse (Clepticus parrae (Bloch and Schneider)) and Brown chromis (Chromis multilineata (Guichenot)), also abundant was the French grunt. The stations included in this subgroup have the same general characteristics as the preceding subgroup (B2). Only two stations form subgroup B4, both of which are near river mouths. Dominant species were Sergeant Major (Abudefduf saxatilis (Linnaeus)), Brown chromis and French grunt.

Fish assemblages. Colorados reef: A total of 107 species of teleost fish were identified during the surveys of the 12 sampling sites (4 stations x 3 habitat types). The most abundant species ( $>2$ individuals per census) for the entire reef were: Bicolor damselfish, Bluehead, Blue chromis, Princess/Striped parrotfish complex, Yellowhead wrasse (Halichoeres garnoti (Valenciennes)) and Black durgon (Melichthys niger (Bloch)). These seven species accounted for almost $60 \%$ of all fish counted.

The number of individuals per census varied from 23 to 252 with a mean of 108.2 \pm 3.4 for the entire reef. The interaction term (habitats types $\mathrm{x}$ stations) of the ANOVA was significant $\left(\mathrm{F}_{6,169}=5.502, \mathrm{p}<0.0001\right)$, so no comparison among levels of single factors was attempted. SNK test for all combinations of habitat types and stations yielded that mean abundance was similar in most cases (Table 3 ) with the exception of the crest at station 17, which showed a significantly lower abundance compared to other sites.

After numerical classification, two main groups of samples are very clearly delimited (Fig. 5). In one group, all crest habitats are included. In the other group, all deep habitats (terrace and spur and grooves) were included.

TABLE 3

Mean number of individuals per census ( \pm standard error) at each combination of station and habitat type in Los Colorados reef

\begin{tabular}{cccc} 
Stations & Spur \& groove & Terrace & Crest \\
\hline 8 & $119.7 \pm 10.2^{\mathrm{a}}$ & $96.7 \pm 11.4^{\mathrm{a}}$ & $124.7 \pm 14.1^{\mathrm{a}}$ \\
9 & $92.1 \pm 6.3^{\mathrm{a}}$ & $104.2 \pm 8.5^{\mathrm{a}}$ & $91.6 \pm 9.4^{\mathrm{a}}$ \\
17 & $114.1 \pm 16.7^{\mathrm{a}}$ & $134.3 \pm 11.2^{\mathrm{a}}$ & $52.6 \pm 6.5^{\mathrm{b}}$ \\
19 & $110.9 \pm 6.9^{\mathrm{a}}$ & $134.3 \pm 9.8^{\mathrm{a}}$ & $123.0 \pm 10.6^{\mathrm{a}}$
\end{tabular}

Same super indexes indicate that there were not significant differences among those means (after SNK test on fourth-root transformed data). Number of census was always 15 . 

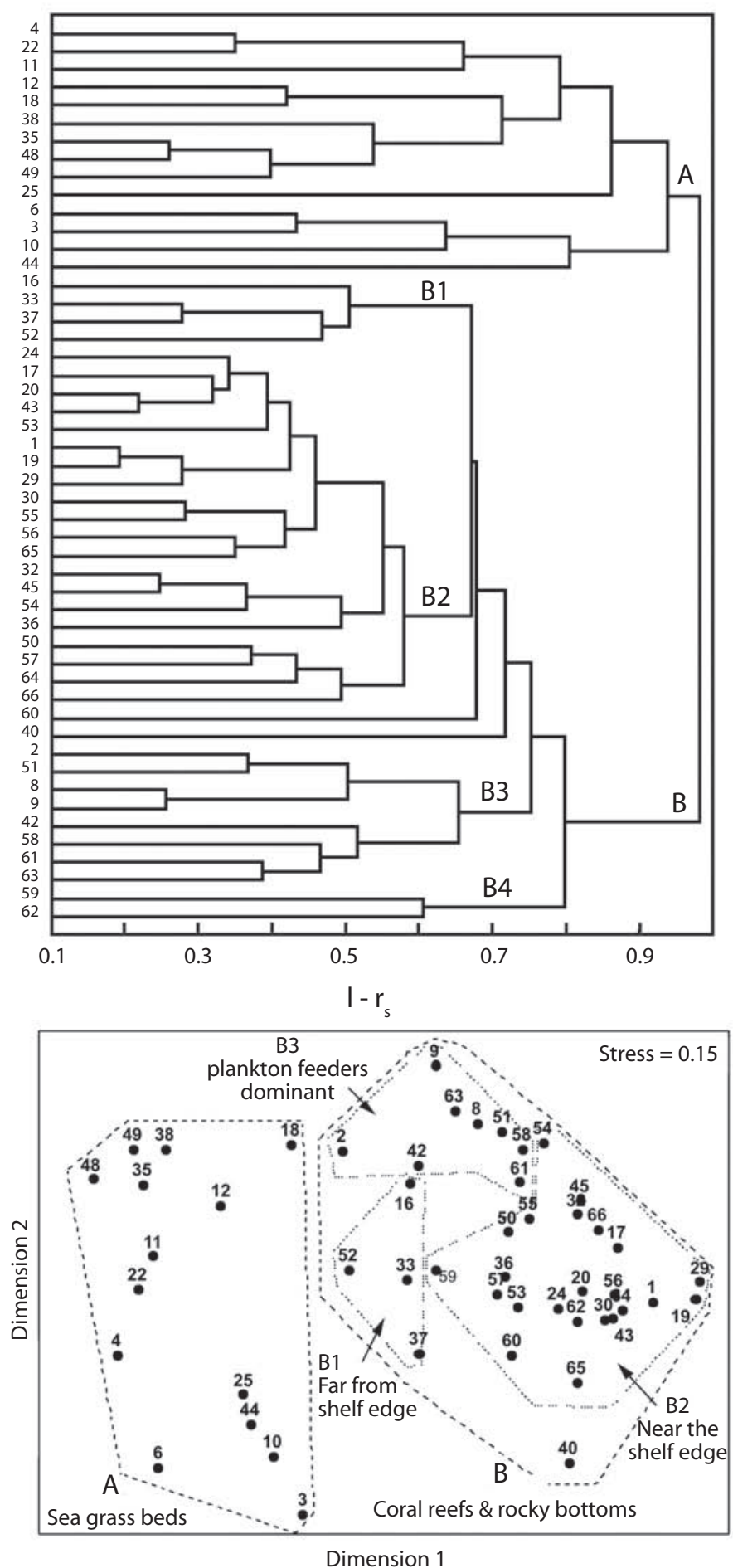

Fig. 4. Dendrogram and 2 first dimensions diagram of a 3 dimensions MDS ordination for the stations in the whole Cuban NW region. 

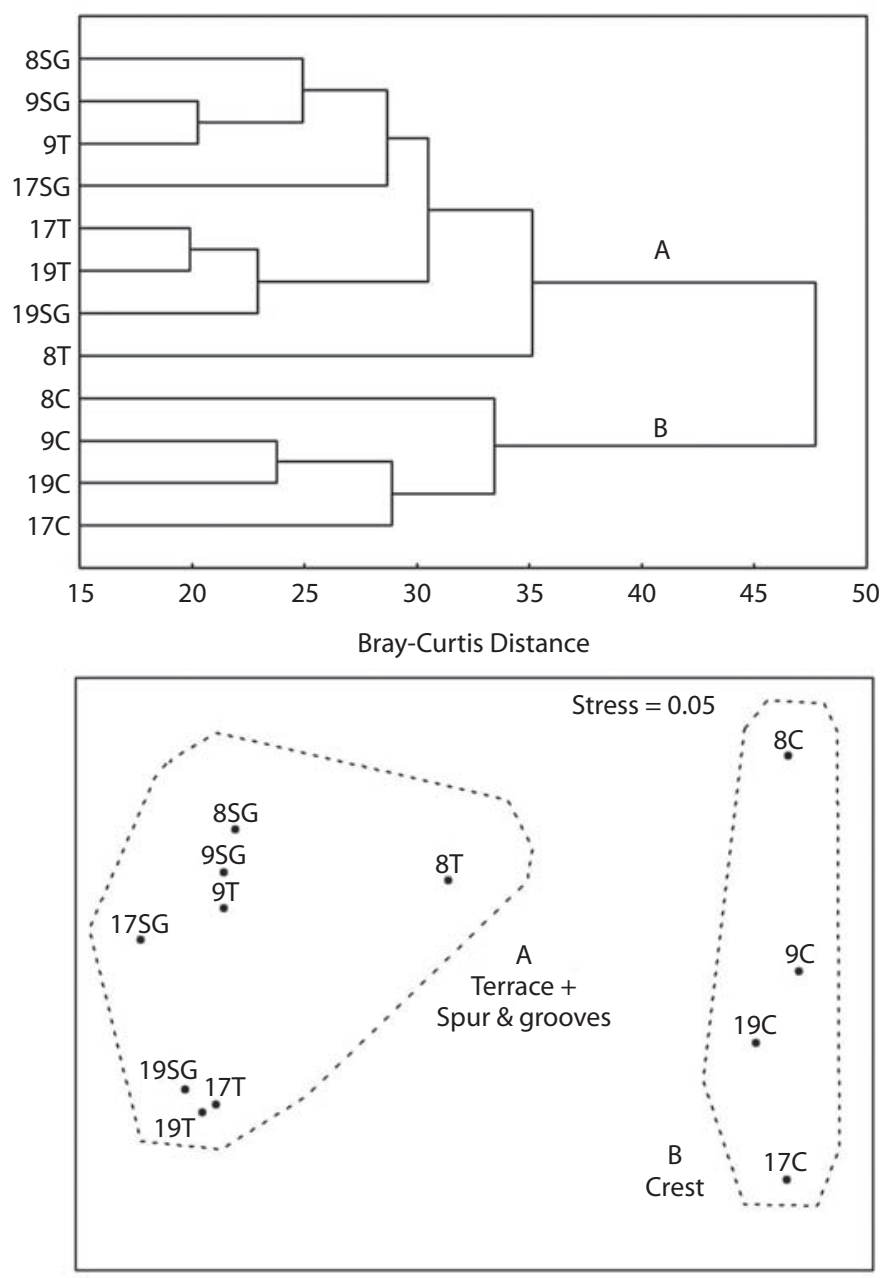

Fig. 5. Dendrogram and MDS ordination of the stations and biotopes in Los Colorados reef. Stations are identified by their numbers and the biotopes by letters: $\mathrm{C}=\mathrm{Crest} ; \mathrm{T}=$ terrace; $\mathrm{SG}=$ Spur and grooves.

The MDS ordination of the samples showed a stress value for two dimensions which can be considered very good (Fig. 5). Results are consistent with cluster analysis.

SIMPER analysis helped locate the pattern of individual species variation between the two groups defined by classification and ordination (Table 4). A set of species is present only at crest sites or are very scarce in non-crest sites. These are the Redlip blenny (Ophioblennius atlanticus (Silvester)), Dusky damselfish (Stegastes adustus (Troschel)), Sergeant major, Yellowtail damselfish
(Microspathodon chrysurus (Cuvier)) and Yellowtail parrotfish (Sparisoma rubripinne (Valenciennes)). Other groups of species were present only in non-crest, deeper habitats or were very scarce at crest sites. These species were Greenblotch parrotfish (Sparisoma atomarium (Poey)), Red hind (Epinephelus guttatus (Linnaeus)), Sharpnose-puffer (Cantigasther rostrata (Bloch)), Black hamlet (Hypoplectrus nigricans (Walbaum)), Spotted goatfish (Pseudupeneus maculatus (Bloch)) and Royal granma (Granma loreto, Poey). Another set of species was present in both 
TABLE 4

Species contributions to total dissimilarity between the groups formed by crest and non-crest habitats in Los Colorados reef (SIMPER analysis)

\begin{tabular}{|c|c|c|c|c|}
\hline \multirow{2}{*}{ Species } & \multicolumn{2}{|c|}{ Average ind./census } & \multirow{2}{*}{ Contribution } & \multirow{2}{*}{$\begin{array}{l}\text { Cumulative } \\
\% \text { contrib. }\end{array}$} \\
\hline & Non-crest & Crest & & \\
\hline Ophioblennius atlanticus & 0.00 & 7.15 & 1.95 & 4.1 \\
\hline Stegastes adustus & 0.00 & 4.70 & 1.79 & 7.9 \\
\hline Microspathodon chrysurus & 0.00 & 3.92 & 1.76 & 11.5 \\
\hline Gramma loreto & 3.74 & 0.15 & 1.31 & 14.3 \\
\hline Sparisoma atomarium & 1.63 & 0.00 & 1.29 & 17.0 \\
\hline Chromis cyanea & 10.88 & 2.50 & 1.21 & 19.5 \\
\hline Haemulon flavolineatum & 0.31 & 2.78 & 1.08 & 21.8 \\
\hline Abudefduf saxatilis & 0.00 & 2.43 & 1.05 & 24.0 \\
\hline Halichoeres bivittatus & 1.24 & 5.30 & 1.04 & 26.2 \\
\hline Ocyurus chrysurus & 0.60 & 1.45 & 1.02 & 28.3 \\
\hline Halichoeres garnoti & 5.36 & 0.88 & 0.99 & 30.4 \\
\hline Epinephelus guttatus & 0.81 & 0.00 & 0.93 & 32.3 \\
\hline Hypoplectrus nigricans & 0.81 & 0.02 & 0.90 & 34.2 \\
\hline Canthigaster rostrata & 0.49 & 0.00 & 0.84 & 36.0 \\
\hline Caranx ruber & 0.91 & 3.13 & 0.80 & 37.7 \\
\hline Cephalopholis fulva & 2.03 & 0.42 & 0.79 & 39.3 \\
\hline Sparisoma rubripinne & 0.02 & 0.47 & 0.78 & 40.9 \\
\hline Holocentrus rufus & 2.54 & 0.70 & 0.78 & 42.6 \\
\hline Lutjanus apodus & 0.35 & 1.27 & 0.77 & 44.2 \\
\hline Pseudupeneus maculatus & 0.44 & 0.02 & 0.76 & 45.8 \\
\hline Stegastes partitus & 28.14 & 6.48 & 0.75 & 47.3 \\
\hline Chromis multilineata & 0.49 & 0.68 & 0.70 & 48.8 \\
\hline Haemulon sciurus & 0.37 & 0.78 & 0.70 & 50.3 \\
\hline
\end{tabular}

Only higher contributing species adding to $50 \%$ of total dissimilarity (47.71) are shown.

habitat types, but the abundance was clearly higher in one of the groups. More abundant in crest sites were French grunt, Slippery dick, Yellowtail snapper, Bar jack (Caranx ruber (Bloch)) and Schoolmaster (Lutjanus apodus (Walbaum)). More abundant in non-crest sites were Blue chromis, Yellowhead wrasse, Coney (Cephalopholis fulva (Linnaeus)), Longspine Squirrelfish (Holocentrus rufus (Walbaum)) and Bicolor damselfish. It should be noted that some of most abundant species did not make a high contribution to dissimilarity. This is due mainly to the much more even distribution of these species in all habitat types (e.g. Bluehead, Princess/Striped parrotfish).

More than $95 \%$ of the fish censused were less than $25 \mathrm{~cm}$ in total length, with a grand mean of $10.6 \pm 0.06 \mathrm{~cm}$. The analysis of mean size for each habitat type inside each site showed that fish size was relatively homogeneous, although a trend of mean size was apparent along the sites with larger fish at stations 8 and 9 and smaller individuals at stations 17 and 19 (Fig. 6). 


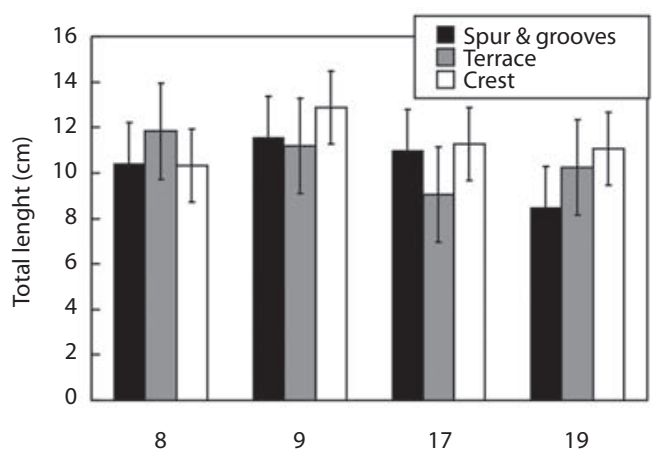

Fig. 6. Mean total length ( \pm standard error) estimated for fish counted in the stations and biotopes of Los Colorados reef.

Fish assemblages. Human impact gradient: A total of 119 fish species were identified during the surveys of the 12 sampling sites along the coast. The most abundant species ( $>2$ individuals/census) for this habitat were: Bicolor damselfish, Bluehead, Blue chromis, Ocean surgeonfish, French grunt, Yellowhead wrasse, Brown chromis and Princess/Striped parrotfish complex. These eight species accounted for little more than $70 \%$ of all fish counted in this habitat.

The number of individuals per census varied from 6 to 336 with a mean of 97.6 \pm 3.1 for the entire terrace habitat. A one-way ANOVA was made on fourth-root transformed data to search for significant differences in the mean total abundance among stations. The null hypothesis of equal means was rejected $\left(\mathrm{F}_{11,315}=5.300, \mathrm{p}<0.0001\right)$. The SNK test failed to define homogeneous non-overlapping groups of means. Nevertheless, it should be emphasized that stations 67 and 68, near the mouth of the Almendares river and the entrance of Havana bay respectively, showed the lowest mean values $(66.1 \pm 9.4$ and $82.2 \pm 6.0$, respectively) while stations at Los Colorados reef (8, 9, 17 and 19) showed much higher mean abundances (from $104.2 \pm 8.4$ to $134.3 \pm 11.2$ ).

The joint interpretation of numerical classification and MDS ordination yielded four main groups of stations (Fig. 7). Group A is formed by only one station (8), which is westernmost in los Colorados reef. Three stations of Los Colorados reef and the station near Bahia Honda (which is a point of reference for change from wide shelf to narrow shelf) form group $\mathrm{B}$. The stations in group $\mathrm{C}$ are all found along the narrow shelf of the eastern subregion. Finally, only the station near the entrance of Havana bay forms group D. Therefore, these groups are well ordered along a coastal gradient from most polluted areas to least polluted ones. SIMPER routine allowed for the location of the species, which contributed more to mean dissimilarity among pairs of groups. Based on these results, three subsets of species where identified according to the trend of their mean abundances along the coast (Table 5). Nine species have a clear trend to decrease abundance towards the east (the most polluted areas). These species were A. coeruleus, Granma loreto, H. plumieri, Halichoeres garnoti, M. niger, Ocyurus chrysurus, S. taeniopterus, Scarus iseri, S. aurofrenatum and T. bifasciatum, Four species showed an opposite trend, increasing their abundance toward the east. This group includes: Acanthurus bahianus, Halichoeres maculipinna, Mulloidichthys martinicus and juveniles of the genus Scarus. Finally, one group of species presented an unimodal trend. Three species (Chromis cyanea, Cephalopholis fulva and S. partitus) showed maximum abundance at groups of stations $\mathrm{B}$ and $\mathrm{C}$, while another one (Halichoeres bivittatus) showed the opposite trend, being most abundant at both extremes of the longitudinal gradient.

The joint analysis of fish size distribution for all sites allowed for the identification of clear patterns of size composition. Fish in size class $3-5 \mathrm{~cm}$ and $6-9 \mathrm{~cm}$ share dominance in most western sites (Colorados reef and Bahia Honda) while in eastern sites, the dominant size class was 3-5 cm. Medium sized (20-44 $\mathrm{cm})$ and larger fishes $(>45 \mathrm{~cm})$ had a higher percentage representation in Los Colorados reef than in the sites from Gobernadora Point to Havana bay. Taken together, these results indicate that fish are larger to the west. The mean size trend supports this statement (Fig. 8). 

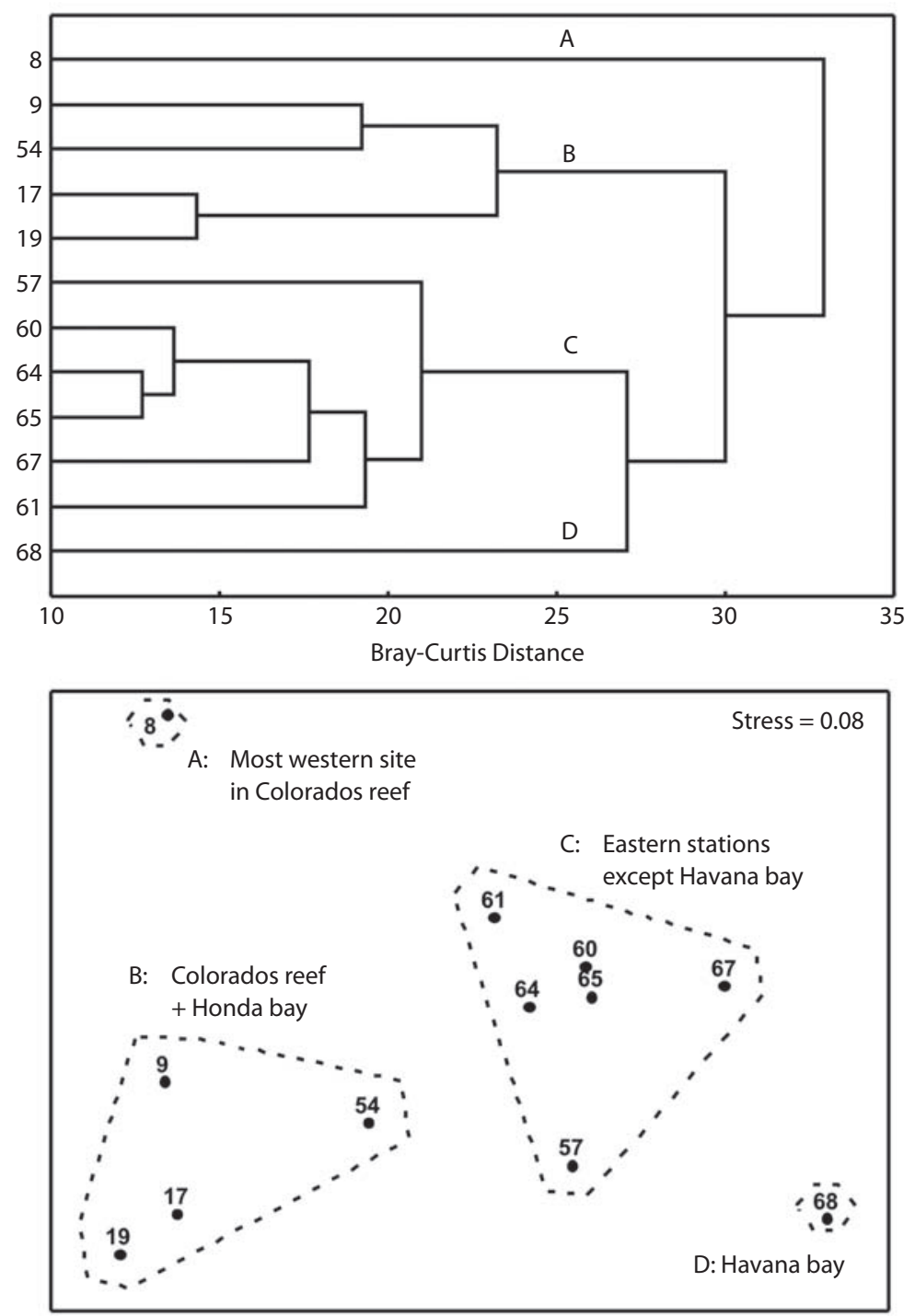

Fig. 7. Dendrogram and MDS ordination of the stations included in the study along the coast (terrace biotope).

Fisheries: Total annual mean catch in the period 1959-1973 was higher in Los Arroyos (687 tons) than in La Esperanza (426 tons). Species composition was different in both places (Fig. 9, left panel). In Los Arroyos, Lane snapper (Lutjanus synagris (Linnaeus)) was clearly the dominant species (33\% of the catch) followed by yellowtail snapper, grunts (Haemulon spp.) and sardines (Harengula spp.). These four categories together formed $75 \%$ of the catch. Less than $20 \%$ of total catch was accounted for more than 60 species. In La Esperanza, there were no dominant species and $65 \%$ of the catches consisted of Nassau grouper (Epinephelus striatus (Bloch)), Yellowtail snapper, grunts and Mutton snapper (Lutjanus analis (Cuvier)) with very similar representa- 
TABLE 5

Mean number of individuals per count for the species determining the clustering of stations along a gradient of human impact

\begin{tabular}{|c|c|c|c|c|}
\hline \multirow{2}{*}{ Species } & \multicolumn{4}{|c|}{ Clusters of stations } \\
\hline & A & B & $\mathrm{C}$ & $\mathrm{D}$ \\
\hline \multicolumn{5}{|c|}{ Less abundant towards the east } \\
\hline Thalassoma bifasciatum & 19.73 & 21.37 & 15.17 & 9.45 \\
\hline Halichoeres garnoti & 1.67 & 4.95 & 1.95 & 0.60 \\
\hline Scarus taeniopterus-iseri & 3.40 & 4.62 & 0.89 & 0.48 \\
\hline Gramma loreto & 6.53 & 2.55 & 0.23 & 0.43 \\
\hline Acanthurus coeruleus & 4.00 & 1.49 & 1.19 & 1.50 \\
\hline Melichthys niger & 2.33 & 3.19 & 0.10 & 0.00 \\
\hline Haemulon plumieri & 5.67 & 1.76 & 0.79 & 0.10 \\
\hline Sparisoma aurofrenatum & 1.73 & 1.95 & 1.42 & 1.03 \\
\hline Ocyurus chrysurus & 3.87 & 0.04 & 0.19 & 0.05 \\
\hline \multicolumn{5}{|c|}{ More abundant towards the east } \\
\hline Acanthurus bahianus & 3.27 & 2.71 & 4.78 & 6.30 \\
\hline Mulloidichthys martinicus & 1.00 & 0.00 & 1.33 & 5.28 \\
\hline Scaridae (juv) & 0.00 & 0.11 & 0.69 & 1.53 \\
\hline Halichoeres maculipinna & 0.27 & 0.21 & 0.05 & 1.23 \\
\hline \multicolumn{5}{|c|}{ More abundant in the middle of the range } \\
\hline Chromis cyanea & 5.27 & 10.69 & 8.25 & 1.45 \\
\hline Stegastes partitus & 5.00 & 29.24 & 36.91 & 18.98 \\
\hline Cepholopholis fulva & 0.40 & 2.26 & 1.59 & 0.70 \\
\hline \multicolumn{5}{|c|}{ Less abundant in the middle of the range } \\
\hline Halichoeres bivittatus & 1.40 & 0.68 & 0.98 & 1.70 \\
\hline
\end{tabular}

tion. In this port, little more than $25 \%$ of the catch consisted of more than 60 species.

The situation in the period 2000-2003 was very different (Fig. 9, right panel). In both ports, catches decreased markedly. The mean annual catch during this period at Los Arroyos was 206 tons while at La Esperanza it was 222 tons. Most species showed much smaller mean catches and two of them, the Nassau grouper and Cubera snapper (Lutjanus cyanopterus (Cuvier)), practically disappeared from the fishery. The trends of some species behave differently in both ports. Sardines decrease in Los Arroyos but increase in La Esperanza the opposite of what occurs to Mutton snapper. Two less valued species increase their catches several fold in both ports, namely the porgies (Calamus spp.) and the jacks (Carangidae). In both ports, little more than $25 \%$ of the total catch was formed by more than 60 species.

\section{DISCUSSION}

The results of this research support the current hypothesis that habitat type is a main factor determining the composition of fish assemblages. This was an expected result and has also been found by several authors working 


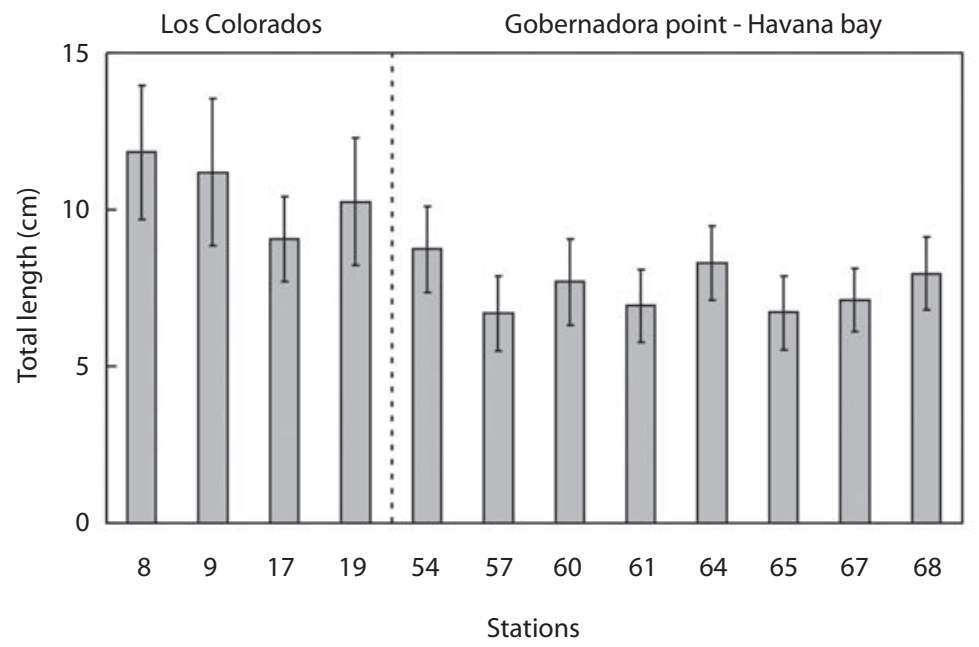

Fig. 8. Mean total length ( \pm standard error) of fish censused at the terrace biotope in stations included in the study along the coast.

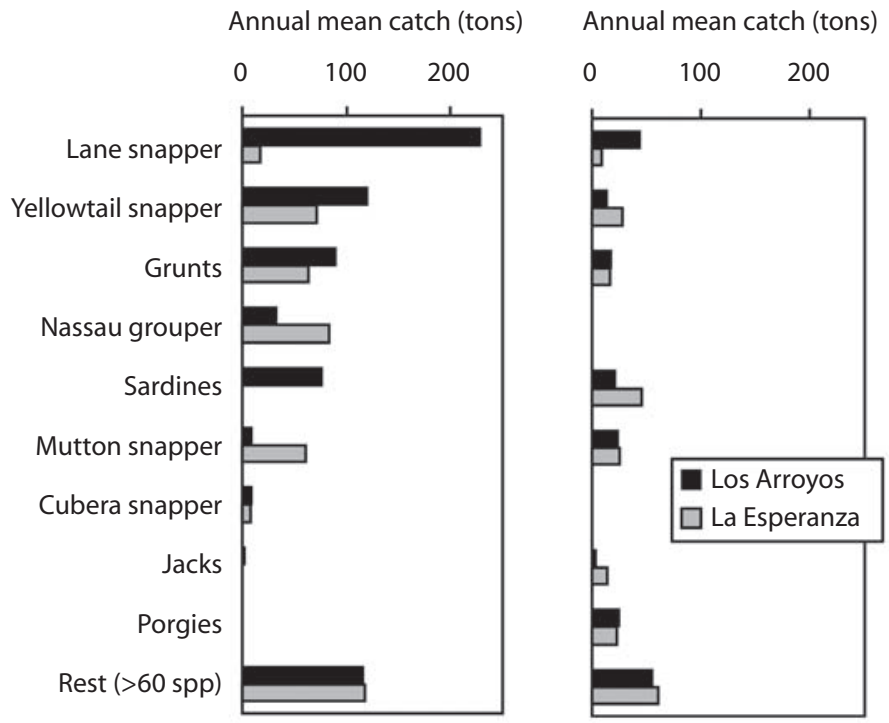

Fig. 9. Species composition of the annual mean catch in two different periods at Los Arroyos and La Esperanza fishing ports.

in different areas of the Caribbean region (McGehee 1994, Ault and Johnson 1998, Núñez-Lara and Arias-Gonzalez 1998, Aguilar et al. 2004, Chittaro et al. 2005, Dorenbosch et al. 2005, Núñez Lara et al. 2005) and in other reef sites in the world (Bell and Galzin 1984,
Chabanet et al. 1997, Nanami et al. 2004, Parrish and Boland 2004). In a review of current literature, it can be verified, however, that the detailed composition of fish assemblages can vary notably from one site to other and that the habitats investigated inside each sampled 
reef are not always the same. For this reason, it is very important to have appropriated data sets for each particular region in order to build a reliable baseline for monitoring and future comparative studies, including before-aftercontrol-impact protocols in the case of environmental impacts. In the present case, detailed information on species composition, abundance and size composition (by species) is stored in an electronically-supported data base.

The magnitude of changes in fish assemblages observed in this study differed notably for different dimensions of spatial variability. There was a marked difference in dominant fish species between stations characterized by sea grass beds and stations positioned in coral reefs or hard bottom areas. For example, 20 species are almost absent in sea grass sites while they have a high constancy in hard bottom localities. The separation among the subgroups inside the group of stations in hard bottoms is, however, much more subtle. We feel that the difference between habitats (sea grass vs hard bottoms) is well supported and can be taken as reference for future monitoring. The differences inside the reef habitat, however, must be taken with caution and should be verified with future additional sampling.

Habitat type was also the major correlate of changes in fish assemblage composition inside Colorados reef. In this case, there exists a clear segregation of species between shallow, Acropora dominated bottoms, and deeper areas of the reefs. The percent similarity analysis (SIMPER) proved an effective discriminating tool and based on the results from this research the characteristic species in shallow and deep areas of these reefs are well defined. This result provides good quantitative data for any monitoring or comparison effort to be made in the future. The fact that no differences among stations in the reef were found suggests that the proximity to the fishing port of Los Arroyos is not a factor influencing the composition of fish assemblages. Station 8 was almost twice the distance from the port than station 19, yet no differences between the composition of their fish assemblages were detected.
In the case of the stations along the coast the sampled habitat was always constant (terrace) although a high variability in the composition of benthic invertebrate assemblages and geomorphologic characteristics of the site samples was to be expected. These uncontrollable features introduce a high variability in fish assemblages' composition and make it more difficult to find differences, which can be explained by a gradient of human impact. Several trends were found, however, which can partially explain the differences along the coast.

The Bray-Curtis index used for numerical classification and ordination is sensitive to abundance of the species. Therefore, stations where the same species are present but have different abundance will be dissimilar. The observed trend of nine species to decrease their abundance toward the east and four species with an opposite trend will explain the turnover of quantitative species composition along the coast. As both trends compensate, the trend in the change in mean total number of individuals per census was not so clear, although there is strong evidence of lower abundance at the east, near the most polluted sites. We feel that these results indicate that habitat degradation due to pollution (mainly increased sedimentation and eutrophication) affect an important group of species while some others, perhaps more resistant, can take advantage of this. For a full explanation of these trends new studies will be needed which include some kind of experimental manipulation.

A group of species behaves in a more complex fashion. They were less abundant at the extremes of the longitudinal gradient, which means that they are equally absent from very polluted and relatively unpolluted sites. One of the species included in this group is the most abundant species in the terrace, the Bicolor damselfish. This species is responsible for a significant contribution to dissimilarity among the cluster groups. It is interesting that slippery dick, an also abundant species, showed an opposite trend, with higher levels of abundance at sites where the other 
species, particularly Bicolor damselfish, were least abundant. A similar result was found by Aguilar et al. (2004) in a more detailed study off Havana city. Jones (2005) concluded that aggressive interaction with a close relative of bicolor damselfish, the Beaugregory (Stegastes leucostictus), affected individual Slippery dick space use and may consequently affect the spatial distribution of its populations. Bullard and Hay (2002) report that the only fish species commonly found on the sand plain was the Slippery dick. Pattengill-Semmens (2002) includes the Slippery dick among the species that primarily utilize the sand habitat. After the reports of several authors, the Slippery dick appears to be more tolerant to siltation than other species of wrasses (Aliaume et al. 1990, Baelde 1990, Bouchon- Navaro et al. 1992, Thomas and Logan 1992).

We hypothesize that there are two factors contributing to the observed abundance trends found for bicolor damselfish and slippery dick. The extension of rocky bottom is higher and the natural sediment (sand) availability is lower in sites forming groups B and C (Fig. 7). Cluster $\mathrm{D}$ is formed only by the site near Havana bay, which has an increased sediment load originating from organic polluted waters of the bay. Cluster site (A) is formed by the very clean station at Los Colorados reef, which has less rocky bottom area and the highest natural sandy plain expanse of all reef stations. This combination favored bicolor damselfish in those places with dominant rocky bottoms and high coral cover and favored slippery dick abundance in sites with high amounts of sediments (natural or due to siltation). Therefore, the change in species composition must be taken cautiously as an indicator of habitat condition. Very different, opposite causes can explain higher or lower abundances of some species.

The observed trend in mean fish size correlates well with a gradient of increasing human impact. The decreasing mean size towards the east can be explained by a higher fishing effort found in most populated places. In the western side of the region only commercial fishing is taking place. The targeted species in this activi- ty are medium- and large-sized fish. In the eastern portion, however, heavy subsistence fishery activity using spear-gun and (illegal) smallmesh sized gill nets also targets small size fish (e.g. small surgeonfish and parrotfish).

In summary, we presented the results of the most comprehensive survey of fish assemblages made in the NW region of the Cuban shelf to date. We show how major differences in fish assemblage composition are correlated with differences in fish habitat at different scales. This is a trend found by many authors (Gladfelter and Gladfelter 1978, Luckhurst and Luckhurst 1978, Roberts and Ormond 1987, Aburto-Oropeza and Balart 2001, Claro et al. 2001, Fock et al. 2002, Letourneur et al. 2003, Gratwicke and Speight 2005, Gratwicke et al. 2006, Feary et al. 2007) For a relatively homogeneous habitat (terrace) we showed the effects of human impact in the composition of fish assemblage and fish mean size.

\section{ACKNOWLEDGMENTS}

This research was made possible with funding from U.S. based The Bay and Paul Foundations and The Marine Ventures Foundation. The Harte Research Institute for Gulf of Mexico Studies served as the main research partner. Critical reviews by two anonymous referees contributed significantly to enhance the manuscript. The authors are indebted to Elena de la Guardia, Patricia González, Sergio Alvarez, Ana Maria Suarez, Maickel Armenteros and Abel Valdivia, for their enthusiastic participation in bottom community and substrate surveys. Servando Valle kindly provided the catch statistics for the period 2000-2003. We also want to thank to the crew of the diving vessels "Boca del Toro" from the National Flora and Fauna Enterprise and "Pisces" from SERVIMAR.

\section{RESUMEN}

Se obtuvieron datos de campo para una línea base de la composición de la ictiofauna que pueda ser usada comparativamente para el análisis de impactos humanos 
futuros en la región. Se estableció una red básica de 68 estaciones de muestreo para la región completa (4 050 $\mathrm{km}^{2}$ ). La composición por especies y por tallas de la ictiofauna fue estimada utilizando métodos de censo visual en tres escalas espaciales diferentes: a) La región completa, b) dentro del área principal de arrecifes y c) a lo largo de un gradiente costero de impacto humano. El tipo de hábitat es el factor principal que induce la variación espacial en la composición de la ictiofauna, mientras que el impacto humano juega el papel principal en los cambios a lo largo de la costa. La tendencia de la talla de los peces a disminuir hacia el este da soporte a la idea de un impacto humano más severo en esa dirección, debido a la sobrepesca y la contaminación. Este es el primer estudio detallado a lo largo de la costa NW de Cuba que se enfoca a la estructura de la comunidad de peces y sus variaciones naturales o antropogénicas en escalas espaciales diferentes.

Palabras clave: comunidades de peces, Caribe, Golfo de México, impacto humano, escala espacial

\section{REFERENCES}

Aburto-Oropeza, O. \& E.F. Balart. 2001. Community structure of reef fish in several habitats of rocky reef in the Gulf of California. P.S.Z.N. Mar. Ecol. 22: 283-305.

Adams, S.M. 2002. Biological indicators of aquatic ecosystem stress. American Fisheries Society, Bethesda, Maryland, USA.

Aguilar, C. \& G. González-Sansón. 2002. Ecología de la ictiofauna costera en la zona adyacente a la desembocadura del río Almendares (La Habana, Cuba): I. Distribución espacial de la abundancia y la diversidad. Rev. Invest. Mar. 23: 3-14.

Aguilar, C., G. González-Sansón, J. Angulo \& C. González. 1997. Variación espacial y estacional de la ictiofauna en un arrecife de coral costero de la región noroccidental de Cuba. I: Abundancia total. Rev. Invest. Mar. 18: 223-232.

Aguilar, C., G. González-Sansón, K.R. Munkittrick \& D.L. MacLatchy. 2004. Fish assemblages on fringe coral reefs of the northern coast of Cuba near Havana Harbor. Ecotox. Environ. Safe. 58: 126-138.

Aguilar, C., G. González-Sansón, I. Hernández, D.L. MacLatchy \& K.R. Munkittrick. 2007. Effects-based assessment in a tropical coastal system: status of bicolor damselfish (Stegastes partitus) on the north shore of Cuba. Ecotox. Environ. Safe. 67: 459-471.

Aguilar, C., G. González-Sansón, I. Faloh \& A. Curry. 2008. Spatial variation in stable isotopes $\left(\delta^{13} \mathrm{C}\right.$ and $\left.\delta^{15} \mathrm{~N}\right)$ in marine fishes along the coast of Havana City:
Evidence of human impacts from harbor and river waters. J. Coastal Res. 24: 1281-1288.

Aliaume, C., G. Laserre \& M. Louis. 1990. Organisation spatiale des peuplements ichtyologiques des herbiers a' Thalassia du Grand Cul de Sac marin en Guadeloupe. Rev. Hydrobiol. Trop. 23: 231-250.

Ault, T.R. \& C.R. Johnson. 1998. Spatially and temporally predictable fish communities on coral reefs. Ecol. Monogr. 68: 25-50.

Baelde, P. 1990. Differences in the structures of fish assemblages in Thalassia testudinum beds in Guadeloupe, FrenchWest Indies, and their ecological significance. Mar. Biol. 105: 163-173.

Baisre, J. 2000. Chronicle of Cuban marine fisheries (19351995). Trend analysis and fisheries potential. FAO Fish. Tech. Pap. 394: 26 p.

Barletta, M., A. Barletta-Bergan, U. Saint-Paul \& G. Hubold. 2005. The role of salinity in structuring the fish assemblages in a tropical estuary. J. Fish Biol. 66: 45-72.

Baron, R.M., L.K.B. Jordan \& R.E. Spieler. 2004. Characterization of the marine fish assemblage associated with the nearshore hardbottom of Broward County, Florida, USA. Estuar. Coast. Shelf S. 60: 431-443.

Bell, J.D. \& R. Galzin. 1984. Influence of live coral cover on coral-reef fish communities. Mar. Ecol. Prog. Ser. 15: 265-274.

Bohnsack, J.A. \& S.P. Bannerot. 1986. A stationary visual census technique for quantitatively assessing community structure of coral reef fishes. NOAA Tech. Rep. NMFS 41: 15p.

Bouchon-Navaro, Y., C. Bouchon, \& M. Louis. 1992. L'ichthyofaune des herbiers de phanerogames marines de la baie de Fort-de-France (Martinique, Antilles Françaises). Cybium 16: 307-330.

Bullard, S.G. \& M.E. Hay. 2002. Plankton tethering to assess spatial patterns of predation risk over a coral reef and seagrass bed. Mar Ecol. Prog. Ser. 225: 17-28.

Chabanet, P., H. Ralambondrainy, M. Amanieu, G. Faure \& R. Galzin. 1997. Relationships between coral reef substrata and fish. Coral Reefs 16: 93-102.

Chittaro, P.M., P. Usseglio \& P.F. Sale. 2005. Variation in fish density, assemblage composition and relative rates of predation among mangroves, seagrass and coral reef habitats. Environ. Biol. Fish. 72: 175-187. 
Clarke K.R. \& R.M. Warwick. 2001. Change in marine communities: An approach to statistical analysis and interpretation. $2^{\text {nd }}$ ed. Primer-E, Plymouth, UK.

Claro, R., K.C. Lindeman \& L.R. Parenti. 2001. Ecology of the marine fishes of Cuba. Smithsonian Institution, Washington, USA.

Costa de Azevedo, M.C., F. Gerson Araújo, A.L. Machado Pessanha \& M. de Araujo Silva. 2006. Co-occurrence of demersal fishes in a tropical bay in southeastern Brazil: A null model analysis. Estuar. Coast. Shelf S. 66: $315-322$

Dorenbosch, M., M.G.G. Grol, I. Nagelkerken \& G. van der Velde. 2005. Distribution of coral reef fishes along a coral reef-seagrass gradient: edge effects and habitat segregation. Mar. Ecol. Prog. Ser. 299: 277-288.

Feary, D.A., G.R. Almany, G.P. Jones \& M.I. McCormick. 2007. Coral degradation and the structure of tropical reef fish communities. Mar. Ecol. Prog. Ser. 333: 243-248.

Fock, H., F. Uiblein, F. Köster \& H. von Westernhagen. 2002. Biodiversity and species-environment relationships of the demersal fish assemblage at the Great Meteor Seamount (subtropical NE Atlantic), sampled by different trawls. Mar. Biol. 141: 185-199.

Gladfelter, W.B. \& E.H. Gladfelter. 1978. Fish community structure as a function of habitat structure on West Indian patch reefs. Rev. Biol. Trop. 26: 65-84.

Gratwicke, B. \& M.R. Speight. 2005. Effects of habitat complexity on Caribbean marine fish assemblages. Mar. Ecol. Prog. Ser. 292: 301-310.

Gratwicke, B., C. Petrovic \& M.R. Speight. 2006. Fish distribution and ontogenetic habitat preferences in non-estuarine lagoons and adjacent reefs. Environ. Biol. Fish 76: 191-210.

González-Sansón, G. \& C. Aguilar. 2002. Ecología de la ictiofauna costera en la zona adyacente a la desembocadura del río Almendares (La Habana, Cuba): II. Análisis multidimensional. Rev. Invest. Mar. 23: $15-25$.

González-Sansón, G. \& C. Aguilar. 2004. Los ecosistemas marinos de la región nor-occidental de Cuba, p. 603-626. In M. Caso, I. Pisanty \& E. Ezcurra (eds.) Diagnóstico Ambiental del Golfo de México. Instituto Nacional de Ecología, México DF, México.

Gotelli, N.J. \& R.K. Colwell. 2001. Quantifying biodiversity: procedures and pitfalls in the measurement and comparison of species richness. Ecol. Lett. 4: 379-391.
Guardia, E. \& G. González-Sansón. 2000a. Asociaciones de corales, gorgonias y esponjas del sublitoral habanero al oeste de la bahía de La Habana. I Gradiente ambiental. Rev. Invest. Mar. 21: 1-8.

Guardia, E. \& G. González-Sansón. 2000b. Asociaciones de corales, gorgonias y esponjas del sublitoral habanero al Oeste de la bahia de La Habana. II. Indices ecológicos. Rev. Invest. Mar. 21: 9-16.

Guardia, E. de la, P. González \& J. Trelles. 2001. Macrobentos del arrecife coralino adyacente al Río Almendares, Cuba. Rev. Invest. Mar. 22: 167-178.

Harmelin-Vivien, M. 1992. Impact des activités humaines sur les peuplements ichtyologiques des récifs coralliens de Polynésie française. Cybium 16: 279-289.

Herrera, A. \& P. Alcolado. 1983. Efecto de la contaminación sobre las comunidades de gorgonáceos del Oeste de la Bahia de la Habana. Ciencias Biológicas 10: 69-85.

Herrera, A. 1984. Clasificación numérica de las comunidades de gorgonáceos al óeste de la Bahía de la Habana. Ciencias Biológicas 12: 105-124.

Herrera, A. \& Martínez-Estalella. 1987. efecto de la contaminación sobre las comunidades de corales escleractíneos al oeste de la Bahía de la Habana. Cuba. Reporte de Investigación del Instituto de Oceanología 62: 1-29.

Hughes, T.P. 1994. Catastrophes, phase shifts, and largescale degradation of a Caribbean coral reef. Science 265: 1547-1551.

Jones, K.M.M. 2005. The effect of territorial damselfish (family Pomacentridae) on the space use and behaviour of the coral reef fish, Halichoeres bivittatus (Bloch, 1791) (family Labridae). J. Exp. Mar. Biol. Ecol. 324: 99-111.

Letourneur, Y., S. Ruitton \& S. Sartoretto. 2003. Environmental and benthic habitat factors structuring the spatial distribution of a summer infralittoral fish assemblage in the north-western Mediterranean Sea. J. Mar. Biol. Assoc. U.K. 83: 193-204.

Luckhurst, B.E. \& K. Luckhurst. 1978. Analysis of the influence of substrate variables on coral reef communities. Mar. Biol. 49: 317-323.

McGehee, M.A. 1994. Correspondence between assemblages of coral reef fishes and gradients of water motion, depth, and substrate size off Puerto Rico. Mar. Ecol. Prog. Ser. 105: 243-255. 
Munkittrick, K.R., M.E. McMaster, G. van der Kraak, C. Portt, W.N. Gibbons, A. Farwell \& M. Gray. 2000. Development of methods for effects-driven cumulative effects assessment using fish populations: Moose river project. SETAC Technical Publication Series, Pensacola, Florida, USA.

Nanami, A., M. Nishihira, T. Suzuki \& H. Yokochi. 2004. Species-specific habitat distribution of coral reef fish assemblages in relation to habitat characteristics in an Okinawan coral reef. Environ. Biol. Fish. 72: 55-65.

Núñez-Lara E. \& E. Arias-González. 1998. The relationship between reef fish community structure and environmental variables in the southern Mexican Caribbean. J. Fish Biol. 53: 209-221.

Núñez-Lara, E., J.E. Arias-González \& P. Legendre. 2005. Spatial patterns of Yucatan reef fish communities: Testing models using a multi-scale survey design. J. Exp. Mar. Biol. Ecol. 324: 157-169.

Paris, C., R.K. Cowen, R. Claro \& K.C. Lindeman. 2005. Larval transport pathways from Cuban snapper (Lutjanidae) spawning aggregations based on biophysical modeling. Mar. Ecol. Prog. Ser. 296: 93-106

Parrish, F.A. \& R.C. Boland. 2004. Habitat and reef-fish assemblages of banks in the Northwestern Hawaiian Islands. Mar. Biol. 144: 1065-1073.

Pattengill-Semmens, C.V. 2002. The reef fish assemblage of Bonaire Marine Park: an analysis of REEF Fish Survey Project data. Proc. Gulf Caribb. Fish. Inst. 53: 591-605.

Roberts, C.M. \& R.F. Ormond. 1987. Habitat complexity and coral reef fish diversity and abundance on red sea fringing reefs. Mar. Ecol. Prog. Ser. 41: 1-8.

Thomas, M.L.H. \& Logan, A. 1992. A guide to the ecology of shore line and shallow-water marine communities of Bermuda. Bermuda Biol. St. Res. Spec. Pub. 30.

UNEP. 2004. Caribbean Islands, GIWA Regional assessment 4. University of Kalmar, Kalmar, Sweden. 